\title{
Simultaneous Detection of Adenosine Triphosphate and Glucose Based on the Cu-Fenton Reaction
}

\author{
Fei Qu ${ }^{1,2, *(D)}$, Jingwen $\mathrm{Li}^{1,2}$, Wenli Han ${ }^{3}$, Lian Xia ${ }^{1,2}$ and Jinmao You 1,2,4 \\ 1 The Key Laboratory of Life-Organic Analysis, Qufu Normal University, Qufu 273165, China; \\ jingwen0121@163.com (J.L.); xialian01@163.com (L.X.); youjinmao63@163.com (J.Y.) \\ 2 Key Laboratory of Pharmaceutical Intermediates and Analysis of Natural Medicine, \\ Qufu Normal University, Qufu 273165, China \\ 3 Laboratory Animal Center, Chongqing Medical University, Chongqing 400016, China; \\ sophie0904@cqmu.edu.cn \\ 4 Northwest Institute of Plateau Biology, Chinese Academy of Sciences, Xining 810001, China \\ * Correspondence: qufei3323@163.com; Tel.: +86-537-445-6305
}

Received: 28 May 2018; Accepted: 28 June 2018; Published: 4 July 2018

\begin{abstract}
Both adenosine triphosphate (ATP) and glucose are important to human health, and their abnormal levels are closely related to angiocardiopathy and hypoglycaemia. Therefore, the simultaneous determination of ATP and glucose with a single test mode is highly desirable for disease diagnostics and early recognition. Herein, a new fluorescence on/off switch sensing platform is developed by carbon nanodots (CNDs) to detect ATP and glucose simultaneously. The fluorescence of CNDs can be quenched by $\mathrm{Cu}^{2+}$ and hydrogen peroxide $\left(\mathrm{H}_{2} \mathrm{O}_{2}\right)$, due to the formation of hydroxyl radicals $(\cdot \mathrm{OH})$ produced in the $\mathrm{Cu}$-Fenton reaction. Based on the high affinity of $\mathrm{Cu}^{2+}$ with ATP, the fluorescence of $\mathrm{CNDs}$ will recover effectively after adding ATP. Additionally, glucose can be efficiently catalyzed by glucose oxidase (GOx) to generate $\mathrm{H}_{2} \mathrm{O}_{2}$, so the platform can also be utilized to analyze glucose. Under optimum conditions, this sensing platform displays excellent sensitivity and the linear ranges are from 0.1 to $7 \mu \mathrm{M}$ for ATP with a limit of detection (LOD) of $30.2 \mathrm{nM}$, and from 0.1 to $7 \mathrm{mM}$ for glucose with a LOD $39.8 \mu \mathrm{M}$, respectively. Benefiting from the high sensitivity and selectivity, this sensing platform is successfully applied for simultaneous detection of ATP and glucose in human serum samples with satisfactory recoveries.
\end{abstract}

Keywords: simultaneous detection; Cu-Fenton reaction; carbon nanodots; adenosine triphosphate; glucose; satisfactory recoveries

\section{Introduction}

As is well known, both adenosine triphosphate (ATP) and glucose are sources of energy and important for energy metabolism. ATP supplies energy for metabolic processes and glucose is a metabolic intermediate in biological systems. Furthermore, the ATP and glucose levels in blood are indicators of human health conditions. For example, the excessive production of ATP by creatine kinase is the pathogenesis of angiocardiopathy [1] and the aberrant concentration of ATP will cause energy disturbance, resulting in hypoglycaemia, ischemia, and Parkinsons' disease [2]. On the other hand, the high glucose levels will produce diabetes mellitus, which damages the eyes, kidneys, feet, and heart, and also causes a series of angiocardiopathy [3], while hypoglycaemia is usually due to the low concentration of glucose. This means that both the levels of ATP and glucose are related to angiocardiopathy and hypoglycaemia by virtue of the coexistence of ATP and glucose in biological samples [4-7], thus, the simultaneous determination of ATP and glucose with a single test mode is highly desirable for disease diagnostics and early recognition.

A comparison with the traditional methods, such as chromatography and electrochemical techniques [8,9], fluorescence analysis receives a great deal of attention due to its simplicity, rapid response, 
and high selectivity. The fluorescence sensing strategy for ATP is usually developed according to the reaction between ATP and aptamer or between ATP and copper ions $\left(\mathrm{Cu}^{2+}\right)$. For example, ATP-aptamer complexes provided greater protection for gold nanoparticles (AuNPs) against salt-induced aggregation than either aptamer or ATP alone, and the dispersive AuNPs rather than aggregation could efficiently quench the fluorescence of $\mathrm{Tb}$ ion-functionalized carbon dots due to the fluorescence resonance energy transfer [10]. In addition, compared with other cations, ATP has a strong affinity for $\mathrm{Cu}^{2+}$, which can completely quench the emission of perylene diimide functionalized with histidine. Thus, the fluorescence recovery positively correlated with ATP concentrations [11]. On the other hand, many fluorescence glucose sensors based on new fluorescence transduction schemes are already developed [12]. In these reports, the enzyme glucose oxidase (GOx) has been widely employed in glucose sensing because hydrogen peroxide $\left(\mathrm{H}_{2} \mathrm{O}_{2}\right)$ is the main product of the reaction between glucose and GOx. For instance, $\mathrm{H}_{2} \mathrm{O}_{2}$ formed in the oxidization of glucose by GOx, resulting in the fluorescence quenching of carbon nanodots (CNDs) in the presence of $\mathrm{Fe}^{2+}$, and the concentration of glucose could be measured indirectly [13]. Although these reports showed good sensitivity and selectivity, these strategies could not incorporate both elements which responded, respectively, to $\mathrm{Cu}^{2+}$ and $\mathrm{H}_{2} \mathrm{O}_{2}$, so the simultaneous measurement of ATP and glucose could not be achieved. Up to now, only an amperometric biosensor was reported for the simultaneous determination of ATP and glucose [14], and other ways, especially fluorescence techniques, have not been presented.

Herein, it is found that the complex of $\mathrm{Cu}^{2+}$ and $\mathrm{H}_{2} \mathrm{O}_{2}$, rather than either $\mathrm{Cu}^{2+}$ or $\mathrm{H}_{2} \mathrm{O}_{2}$ alone, can quench the fluorescence of CNDs due to the hydroxyl radicals $(\cdot \mathrm{OH})$ produced in the $\mathrm{Cu}$-Fenton reaction [15-17]. By virtue of the binding of ATP to $\mathrm{Cu}^{2+}$ and arising $\mathrm{H}_{2} \mathrm{O}_{2}$ in the reaction between glucose and GOx, ATP and glucose can be simultaneously detected. The linear range of ATP is 0.1 to $7 \mu \mathrm{M}$ and the linear response of glucose is from 0.1 to $7 \mathrm{mM}$. Benefiting from the superior sensitivity and selectivity, this sensing platform is successfully applied for simultaneous detection of ATP and glucose in human serum samples with satisfactory recoveries.

\section{Materials and Methods}

\subsection{Chemicals and Materials}

Ascorbic acid (AA), hydrogen peroxide $\left(\mathrm{H}_{2} \mathrm{O}_{2}\right)$, glucose oxidase (GOx), glucose, galactose, fructose, sucrose, mannose, lactose, sodium citrate, adenosine triphosphate (ATP), cytidine $5^{\prime}$-triphosphate disodium salt (CTP), adenosine $5^{\prime}$-diphosphate (ADP), uridine-5' -triphosphate (UTP), guanosine triphosphate (GTP) were purchased from Aladdin (Shanghai, China). $\mathrm{CH}_{3} \mathrm{COONa}, \mathrm{HCl}$, $\mathrm{KCl}$ and $\mathrm{CuSO}_{4}$ were obtained from Shanghai Shenbo Chemical Co., Ltd., Shanghai, China. All reagents were of analytical grade. All the solutions were prepared using ultrapure water produced with a Millipore-Q water system.

\subsection{Instruments}

The fluorescence spectra were recorded with a Hitachi F-7000 fluorescence spectrophotometer (Tokyo, Japan). Transmission electron microscopy (TEM) images were recorded on a JEM-2100PLUS (JEOL, Japan). The Fourier transform infrared (FT-IR) spectra of the samples were analyzed using Thermo Nicolet Nexus 470 FT-IR ESP spectrometer (Nicolet, WI, USA). The ultraviolet-visible (UV-vis) absorption spectra were obtained on a Cary 300 Bio UV-vis spectrophotometer (Varian, Palo Alto, $\mathrm{CA}, \mathrm{USA}$ ) and the $\mathrm{pH}$ values of solutions were measured using a $\mathrm{pH}$ meter (Mettler Toledo FE20, Zurich, Switzerland).

\subsection{Synthesis of CNDs}

Typically, $0.8 \mathrm{~g}$ AA was dissolved in $20 \mathrm{~mL}$ water. Then the above solution was stirred thoroughly and then transferred into a $50 \mathrm{~mL}$ autoclave reactor. The reactor was heated to $160{ }^{\circ} \mathrm{C}$ in a constant temperature drying oven for $70 \mathrm{~min}$. After cooling to room temperature, a clear yellow aqueous 
dispersion containing CNDs was gained. Subsequently, the resulting yellow solution $(20 \mathrm{~mL})$ was dried in a drying oven at $60^{\circ} \mathrm{C}$ to constant weight (for about $14 \mathrm{~h}$ ). Then, $39 \mathrm{mg}$ powder of carbon nanodots was weighed and diluted in $1 \mathrm{~mL}$ water to obtain CNDs solution $(39 \mathrm{mg} / \mathrm{mL})$. The prepared solution of CNDs was diluted 100 times before use, and the concentration was $0.39 \mathrm{mg} / \mathrm{mL}$.

\subsection{Fluorescence Responses of $\mathrm{Cu}^{2+}$}

The fluorescence detection of $\mathrm{Cu}^{2+}$ was performed as follows: briefly, $35 \mu \mathrm{L}$ CNDs $(0.39 \mathrm{mg} / \mathrm{mL})$, $50 \mu \mathrm{L} \mathrm{H}_{2} \mathrm{O}_{2}(0.1 \mathrm{M})$, different concentrations of $\mathrm{Cu}^{2+}, 200 \mu \mathrm{L} \mathrm{HCl}-\mathrm{CH}_{3} \mathrm{COONa}$ buffers $(\mathrm{pH}=5)$ and water were mixed together, and the final volume was $1 \mathrm{~mL}$. After incubation for $10 \mathrm{~min}$ at room temperature, the fluorescence of the mixture was measured at $380 \mathrm{~nm}$ with an excitation of $315 \mathrm{~nm}$. With increasing the concentration of $\mathrm{Cu}^{2+}$, the fluorescence of CNDs decreased linearly and the fluorescence differences were expressed as $\mathrm{F}_{0}-\mathrm{F}$, in which $\mathrm{F}_{0}$ and $\mathrm{F}$ represented the fluorescence intensities of $\mathrm{CNDs}-\mathrm{H}_{2} \mathrm{O}_{2}$ in the absence and presence of $\mathrm{Cu}^{2+}$, respectively.

Additionally, the LOD is the limit of detection, which is defined as the concentration of analyte that corresponds to three times the signal-to-noise ratio $(\mathrm{S} / \mathrm{N}=3)$ [18]. LOD is calculated according to the expression $\mathrm{LOD}=3 \sigma / \mathrm{K}$, where $\sigma$ is the standard deviation for the blank solution $(n=10)$, and $\mathrm{K}$ is the slope of the calibration curve.

\subsection{Fluorescent $\mathrm{H}_{2} \mathrm{O}_{2}$ Assay}

A typical $\mathrm{H}_{2} \mathrm{O}_{2}$ detection procedure was conducted as follows: Firstly, $35 \mu \mathrm{L} \mathrm{CNDs}(0.39 \mathrm{mg} / \mathrm{mL})$, $60 \mu \mathrm{L} \mathrm{Cu}{ }^{2+}(0.01 \mathrm{mM}), 200 \mu \mathrm{L} \mathrm{HCl}-\mathrm{CH}_{3} \mathrm{COONa}$ buffers $(\mathrm{pH}=5)$, various concentrations of $\mathrm{H}_{2} \mathrm{O}_{2}$ and water were mixed thoroughly. The final volume of the mixture was $1 \mathrm{~mL}$. After incubation for $10 \mathrm{~min}$ at ambient temperature, the concentration of $\mathrm{H}_{2} \mathrm{O}_{2}$ linearly responded to the fluorescence differences of $\mathrm{F}_{1}-\mathrm{F}_{2}\left(\mathrm{~F}_{1}\right.$ and $\mathrm{F}_{2}$ represented the fluorescence intensity of $\mathrm{CNDs}^{-\mathrm{Cu}^{2+}}$ in the absence and presence of $\mathrm{H}_{2} \mathrm{O}_{2}$ ).

\subsection{Fluorescence Detection of ATP}

The assay was carried out as follows: (i) $200 \mu \mathrm{L} \mathrm{HCl}-\mathrm{CH}_{3} \mathrm{COONa}$ buffers $(\mathrm{pH}=5), 60 \mu \mathrm{L} \mathrm{Cu}^{2+}$ $(0.01 \mathrm{mM})$ and ATP with different concentrations were added to a certain amount of water and reacted for $10 \mathrm{~min}$ at room temperature; (ii) $35 \mu \mathrm{L} \mathrm{CNDs}(0.39 \mathrm{mg} / \mathrm{mL})$ and $50 \mu \mathrm{L} \mathrm{H}_{2} \mathrm{O}_{2}(0.1 \mathrm{M})$ were injected to the mixture and the volume of final solution was $1 \mathrm{~mL}$. After the mixture reacted for $10 \mathrm{~min}$ at room temperature, a linear correlation was found between the concentration of ATP and the fluorescence differences of $\mathrm{F}_{4}-\mathrm{F}_{3}$, in which $\mathrm{F}_{3}$ was the fluorescence intensity of $\mathrm{CNDs}-\mathrm{Cu}^{2+}-\mathrm{H}_{2} \mathrm{O}_{2}$ system and $\mathrm{F}_{4}$ was the fluorescence intensity of the system with the addition of various concentrations of ATP.

\subsection{Fluorescence Measurement of Glucose}

Firstly, the mixture containing $13 \mu \mathrm{L}$ GOx $(765 \mathrm{U} / \mathrm{mL})$ and different concentrations of glucose was incubated at $37^{\circ} \mathrm{C}$ for $60 \mathrm{~min}$, and then $200 \mu \mathrm{L} \mathrm{HCl}-\mathrm{CH}_{3} \mathrm{COONa}$ buffers $(\mathrm{pH}=5), 60 \mu \mathrm{L} \mathrm{Cu}{ }^{2+}(0.01 \mathrm{mM})$ and $35 \mu \mathrm{L} \mathrm{CNDs}(0.39 \mathrm{mg} / \mathrm{mL})$ were added to the mixture. Ten minutes later, their fluorescence spectra were recorded. The concentration of glucose linearly responded to the fluorescence differences of $\mathrm{F}_{5}-\mathrm{F}_{6}$, where $\mathrm{F}_{5}$ and $\mathrm{F}_{6}$ were the fluorescence of $\mathrm{CNDs}-\mathrm{Cu}^{2+}$-GOx system in the absence and presence of glucose.

\subsection{Real Sample Detection}

The real sample detection in our assay was carried out as follows: Typically, a $1.5 \mathrm{~mL}$ blood sample was kept at $37^{\circ} \mathrm{C}$ in a water bath for about $0.5 \mathrm{~h}$. Then, $3.0 \mathrm{~mL}$ acetonitrile was added and followed by centrifugation at $4000 \mathrm{rpm}$ for $20 \mathrm{~min}$ to remove large molecules and proteins. Subsequently, the supernatant was removed and kept in a water bath $\left(60^{\circ} \mathrm{C}\right)$ for about $1 \mathrm{~h}$ to evaporate acetonitrile. The supernatant of the serum sample was diluted 10 times and measured by the present sensing system 
to detect ATP and glucose. Then, the standard ATP and glucose solutions with different concentrations were spiked into the human serum samples, respectively, to investigate the reliability of this assay.

\subsection{Validation Test of $T M B$}

The validation of the $\mathrm{Cu}$-Fenton activity was performed as follows: the experiments were performed in $200 \mu \mathrm{L} \mathrm{HCl}-\mathrm{CH}_{3} \mathrm{COONa}$ buffers $(\mathrm{pH}=5)$ containing $5 \mathrm{mM} \mathrm{TMB}, 500 \mathrm{mM} \mathrm{H}_{2} \mathrm{O}_{2}$ and differing concentrations of $\mathrm{Cu}^{2+}$ followed by the addition of water to a final volume of $1 \mathrm{~mL}$. After reaction for $10 \mathrm{~min}$, the colour was present in these samples.

\section{Results and Discussion}

\subsection{Characterization of CNDs}

As shown in the TEM image (Figure 1a), the CNDs exhibit an approximately spherical shape and are well-dispersed. These nanoparticles have a size distribution from 1 to $3.4 \mathrm{~nm}$ and the average diameter of CNDs is about $1.8 \mathrm{~nm}$ by estimating the size of 100 dots in the TEM image. The structure and composition of CNDs are characterized by FT-IR spectroscopy (Figure 1b). The CNDs have a main absorption of $\mathrm{C}-\mathrm{H}$ stretching vibration at $2900 \mathrm{~cm}^{-1}$, the $\mathrm{C}=\mathrm{O}$ stretching at $1740 \mathrm{~cm}^{-1}$, and the peak at $3452 \mathrm{~cm}^{-1}$ is related to the $\mathrm{C}-\mathrm{OH}$ bond stretching vibrations. It demonstrates the presence of oxygen-containing functional groups such as hydroxyl and carbonyl groups on the surface of particles. Additionally, these nanodots show a strong peak at $260 \mathrm{~nm}$ (Figure 1c), which is ascribed to $\pi-\pi^{*}$ transition of carbon [19]. Next, the emission is found to be excitation-dependent, including wavelength and intensity in a well-regulated mode within the exciting range of $285-345 \mathrm{~nm}$ (Figure S1). Although the emission peak shifts from 375 to $390 \mathrm{~nm}$ with increasing excitation wavelengths, its intensity reaches a maximum at $315 \mathrm{~nm}$ excitation (Figure 1c). The excitation-dependent emission spectra have been reported by various works involving CNDs [20,21]. Meanwhile, the CNDs solution under UV light exhibits bright blue fluorescence, whereas it is yellow under daylight.
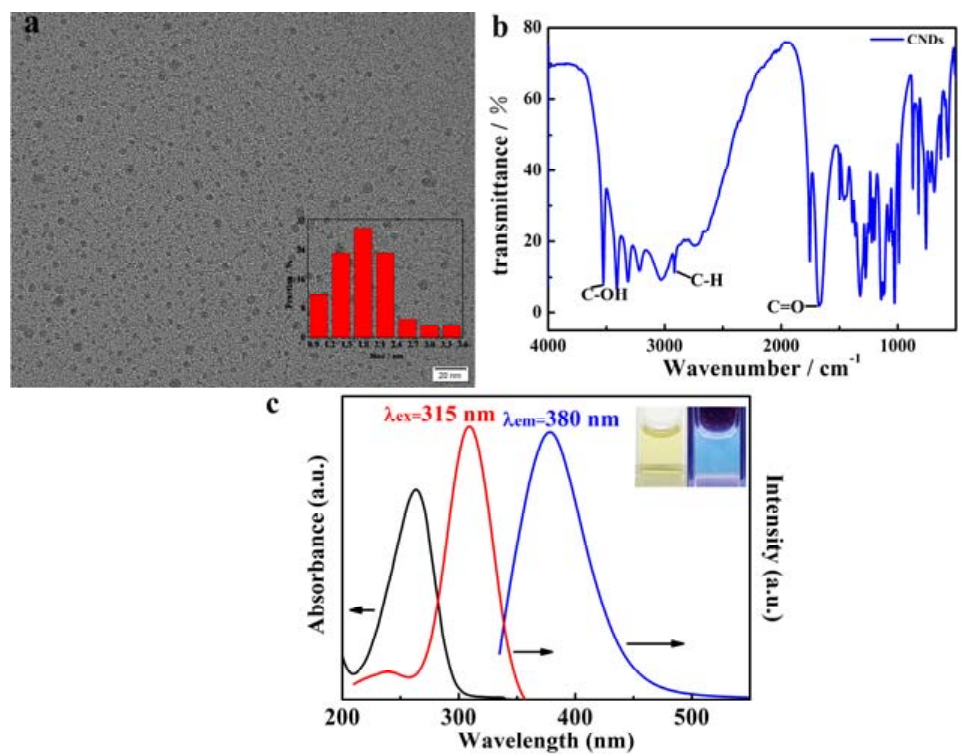

Figure 1. TEM image (a), FT-IR spectrum (b), UV-VIS absorption (black curve), and fluorescence emission (blue curve), and excitation (red curve) spectra of CNDs (c). The inset of (c) is the photograph of CNDs under visible light and UV light at $365 \mathrm{~nm}$.

\subsection{Fluorescence Quenching of CNDs}

According to Figure 2, when only $\mathrm{H}_{2} \mathrm{O}_{2}$ or $\mathrm{Cu}^{2+}$ is mixed with CNDs, the emission at $380 \mathrm{~nm}$ changes inconspicuously. However, by both adding $\mathrm{H}_{2} \mathrm{O}_{2}$ and $\mathrm{Cu}^{2+}$, the fluorescence of CNDs is 
quenched effectively. While the amount of $\mathrm{H}_{2} \mathrm{O}_{2}$ is fixed, the emission of CNDs sensitively responds to the concentration of $\mathrm{Cu}^{2+}$ in the range from $1 \mathrm{nM}$ to $2 \mu \mathrm{M}$ with LOD $0.65 \mathrm{nM}$ (Figure S2), which is lower than most works [22,23]. Additionally, it should be noted that when the concentration of $\mathrm{Cu}^{2+}$ is higher than $4 \mu \mathrm{M}$ (Figure S3), it can directly quench the fluorescence of CNDs without the addition of $\mathrm{H}_{2} \mathrm{O}_{2}$, which is consistent with previous literature [24], but $\mathrm{Cu}^{2+}$ ions with a low amount (especially below $2 \mu \mathrm{M}$ ) is invalid. Additionally, with the unchanged amount of $\mathrm{Cu}^{2+}$, the fluorescence of these nanoparticles also decreases linearly when the concentration of $\mathrm{H}_{2} \mathrm{O}_{2}$ increases from $25 \mu \mathrm{M}$ to $5 \mathrm{mM}$ with LOD 7.8 $\mu \mathrm{M}$ (Figure S4). Like the Fenton reaction between $\mathrm{Fe}^{2+}$ and $\mathrm{H}_{2} \mathrm{O}_{2}, \mathrm{Cu}^{2+}$ and $\mathrm{H}_{2} \mathrm{O}_{2}$ can also produce the reactive $\cdot \mathrm{OH}$. In this process, $\mathrm{Cu}^{2+}$ oxidizes $\mathrm{H}_{2} \mathrm{O}_{2}$ to generate $\mathrm{O}_{2}{ }^{\bullet}$ and $\mathrm{Cu}^{+}$, and $\mathrm{Cu}^{+}$ is able to react with excess $\mathrm{H}_{2} \mathrm{O}_{2}$ to form $\cdot \mathrm{OH}$ [25-28], which can catalyse the oxidation of TMB to produce the blue colour reaction (Figure S5). TMB oxidation-induced colour development is positively correlated with $\mathrm{Cu}^{2+}$ concentrations. Therefore, the $\cdot \mathrm{OH}$ is believed to quench the fluorescence of $\mathrm{CNDs}$, and the quenching efficiency reaches the maximum at $\mathrm{pH} 5$ (Figure S6). Cu-Fenton reaction is different from the Fe-Fenton reaction, and it usually requires a small amount of $\mathrm{Cu}^{2+}$ and a large amount of $\mathrm{H}_{2} \mathrm{O}_{2}$, which just correspond to the low concentration of ATP and high concentration of glucose in human serum. Based on the binding of ATP to $\mathrm{Cu}^{2+}$ and arising $\mathrm{H}_{2} \mathrm{O}_{2}$ in the reaction between glucose and GOx, ATP, and glucose can be simultaneously detected with a single test mode (Scheme 1).

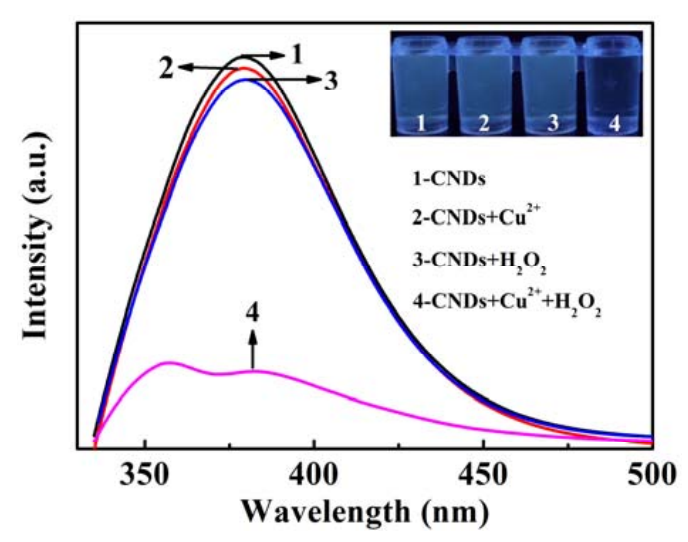

Figure 2. Fluorescence spectra of CNDs in the absence and presence of $\mathrm{Cu}^{2+}, \mathrm{H}_{2} \mathrm{O}_{2}$, and the mixture of $\mathrm{Cu}^{2+}$ and $\mathrm{H}_{2} \mathrm{O}_{2}$, respectively. The concentrations of $\mathrm{CNDs}, \mathrm{Cu}^{2+}$, and $\mathrm{H}_{2} \mathrm{O}_{2}$ were $0.014 \mathrm{mg} / \mathrm{mL}, 2 \mu \mathrm{M}$, and $5 \mathrm{mM}$, respectively.

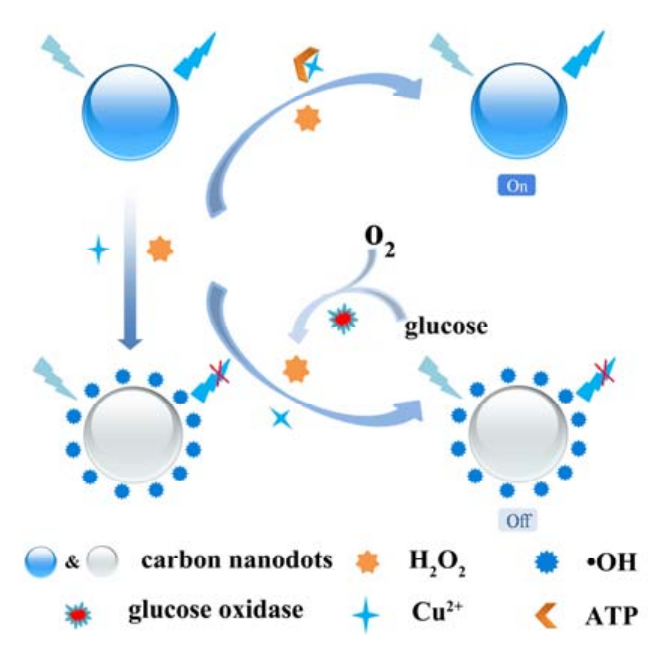

Scheme 1. Schematic illustration of the CNDs as a fluorescence probe for the detection of ATP and glucose. 


\subsection{Fluorescence Recovery of CNDs-Cu $u^{2+}-\mathrm{H}_{2} \mathrm{O}_{2}$ System by ATP}

As shown in Figure 3, when the ATP is introduced in the CNDs-Cu ${ }^{2+}-\mathrm{H}_{2} \mathrm{O}_{2}$ system, the quenched fluorescence recovers effectively because $\mathrm{Cu}^{2+}$ ions exhibit a strong binding affinity to ATP with respect to multiple phosphates, while ATP alone will not influence the fluorescence of CNDs, CNDs-Cu${ }^{2+}$, and $\mathrm{CNDs}-\mathrm{H}_{2} \mathrm{O}_{2}$. All of results indicate that ATP indeed binds with $\mathrm{Cu}^{2+}$ ions, which cannot react with $\mathrm{H}_{2} \mathrm{O}_{2}$ to form $\cdot \mathrm{OH}$. At the same time, the reaction between ATP and $\mathrm{Cu}^{2+}$ ions can complete within $10 \mathrm{~min}$, suggesting a rapid reaction rate (Figure S7). The enhanced fluorescence positively correlates with the concentration of ATP in the linear range from 0.1 to $7 \mu \mathrm{M}$ with LOD $30.2 \mathrm{nM}$ (Figure 4). Comparing with the previous reports (Table 1), our method is not inferior to others [29-35] and also exhibits relatively wide linear ranges and a low limit of detection of ATP.

Table 1. Comparison of analysis methods for the detection of ATP.

\begin{tabular}{ccccc}
\hline Method & Probe & Linear Range & LOD & Ref. \\
\hline Fluorescence & Ru complex & $0-0.1 \mu \mathrm{M}$ & $20 \mathrm{nM}$ & 29 \\
\hline Fluorescence & $\begin{array}{c}\text { DNA template Ag } \\
\text { nanoclusters (AgNCs) }\end{array}$ & $0.5-8.0 \mu \mathrm{M}$ & $91.6 \mathrm{nM}$ & 30 \\
\hline Colorimetric detection & Gold nanoparticles & $4.4-132.7 \mu \mathrm{M}$ & $0.6 \mu \mathrm{M}$ & 31 \\
\hline Fluorescence & $\begin{array}{c}\text { Cysteamine capped CdS } \\
\text { quantum dots (QDs) }\end{array}$ & $20-80 \mu \mathrm{M}$ & $17 \mu \mathrm{M}$ & 32 \\
\hline Fluorescence & DNA binding dye berberine & $0.5-50 \mu \mathrm{M}$ & $140 \mathrm{nM}$ & 1 \\
\hline Fluorescence & QD-tagged aptamer & $0.1-1 \mathrm{mM}$ & $24 \mu \mathrm{M}$ & 33 \\
\hline Electrochemical & labeled anti-ATP aptamer & $10 \mathrm{nM}-1 \mathrm{mM}$ & - & 34 \\
\hline $\begin{array}{c}\text { Fluorescence and } \\
\text { Colorimetric detection }\end{array}$ & cationic polythiophene derivative & $10^{-8}-10^{-4} \mathrm{M}$ & - & 35 \\
\hline Fluorescence & CNDs & $0.1-7 \mu \mathrm{M}$ & $30.2 \mathrm{nM}$ & This work \\
\hline
\end{tabular}

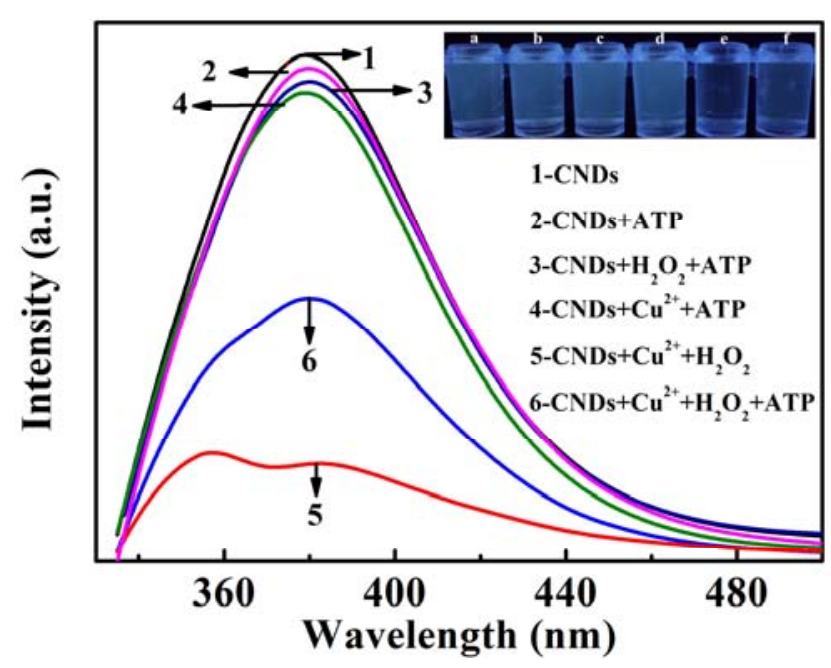

Figure 3. Fluorescence spectra of free CNDs (1) and CNDs in the presence of ATP (2), $\mathrm{H}_{2} \mathrm{O}_{2}$ and ATP (3), $\mathrm{Cu}^{2+}$ and ATP (4), $\mathrm{Cu}^{2+}$ and $\mathrm{H}_{2} \mathrm{O}_{2}$ (5) and $\mathrm{Cu}^{2+}, \mathrm{H}_{2} \mathrm{O}_{2}$, and ATP (6). The final concentrations of CNDs, $\mathrm{H}_{2} \mathrm{O}_{2}, \mathrm{Cu}^{2+}$, and ATP were $0.014 \mathrm{mg} / \mathrm{mL}, 5 \mathrm{mM}, 600 \mathrm{nM}$ and $7 \mu \mathrm{M}$ respectively. The inset shows the corresponding images under UV light. 

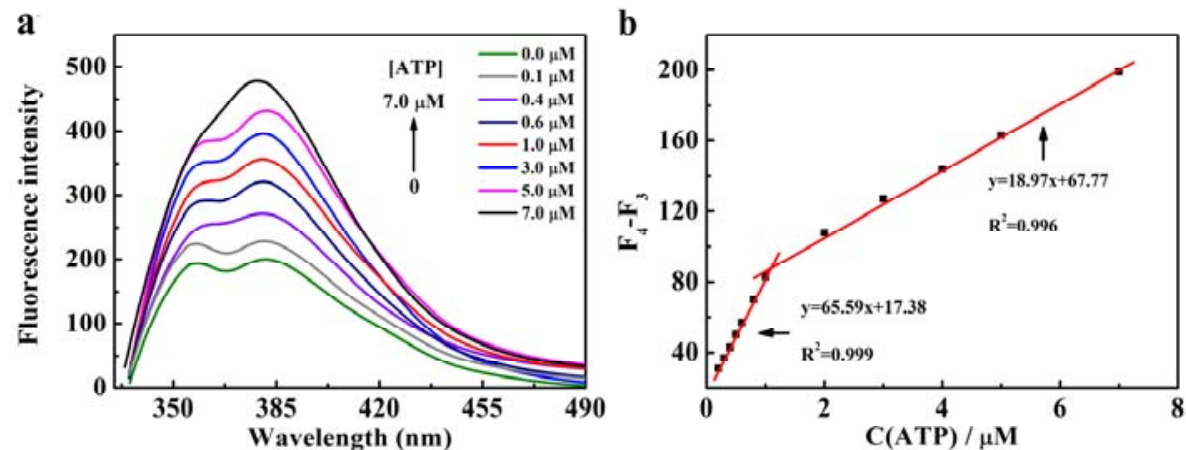

Figure 4. Fluorescence responses to different concentrations of ATP (a) and corresponding linear ranges (b). The concentrations of CNDs, $\mathrm{H}_{2} \mathrm{O}_{2}$ and $\mathrm{Cu}^{2+}$ were $0.014 \mathrm{mg} / \mathrm{mL}, 5 \mathrm{mM}$ and $600 \mathrm{nM}$, respectively.

\subsection{Detection of Glucose Based on CNDs-Cu ${ }^{2+}$ System}

$\mathrm{H}_{2} \mathrm{O}_{2}$ is the main product of the reaction between glucose and GOx, so CNDs- $\mathrm{Cu}^{2+}-\mathrm{H}_{2} \mathrm{O}_{2}$ system can be utilized to analyse glucose. As illustrated in Figure 5, there is no significant difference when glucose or GOx is added in CNDs and CNDs- $\mathrm{Cu}^{2+}$ system. When glucose is oxidized by GOx, the fluorescence of $\mathrm{CNDs}-\mathrm{Cu}^{2+}$ platform was quenched effectively. The fluorescence difference was proportional to the concentration of glucose in the range from 0.1 to $7 \mathrm{mM}$ with LOD $39.8 \mu \mathrm{M}$ (Figure 6). The fluorescence response of this platform to the glucose ranging from 0 to $1.0 \mathrm{mM}$ is depicted in Figure S8, where the slope of the linear equation is similar to that of glucose with concentration from 0.1 to $7.0 \mathrm{mM}$, indicating that the glucose with low concentrations can be also sensitively detected. In comparison with the reported studies (Table 2), this new strategy is demonstrated to not be inferior to other works [36-41]. Additionally, CNDs involved in this assay, as a novel probe, are easily synthesized, experimentally convenient, and low-cost, and can be used to detect ATP and glucose simultaneously.

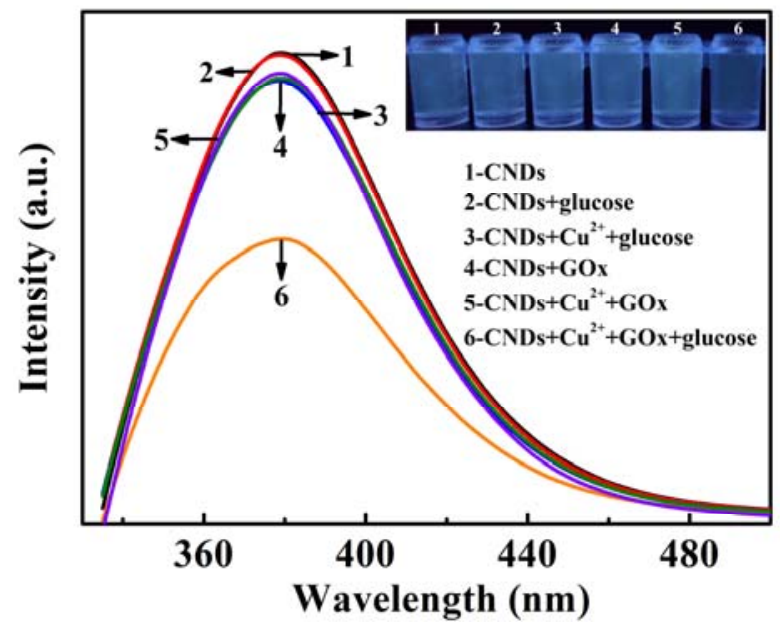

Figure 5. Fluorescence spectra of free CNDs (1) and CNDs in the presence of glucose (2), $\mathrm{Cu}^{2+}$ and glucose (3), GOx (4), $\mathrm{Cu}^{2+}$ and GOx (5), and the mixture of $\mathrm{Cu}^{2+}$, glucose and GOx (6). The final concentrations of CNDs, glucose, $\mathrm{Cu}^{2+}$ and GOx were $0.014 \mathrm{mg} / \mathrm{mL}, 5 \mathrm{mM}, 600 \mathrm{nM}$ and $10 \mathrm{U} / \mathrm{mL}$ respectively. The inset shows the corresponding images under UV light at $365 \mathrm{~nm}$. 
a

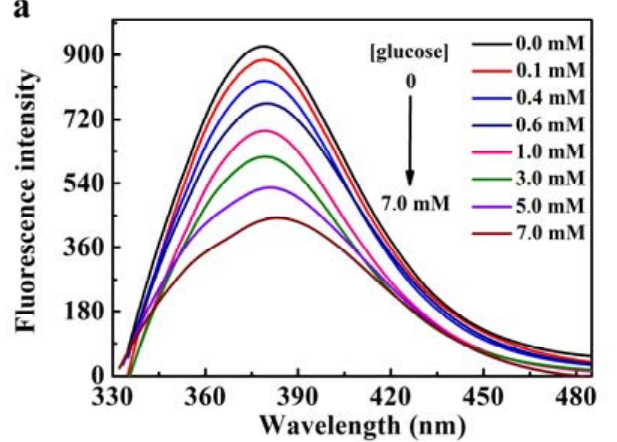

b

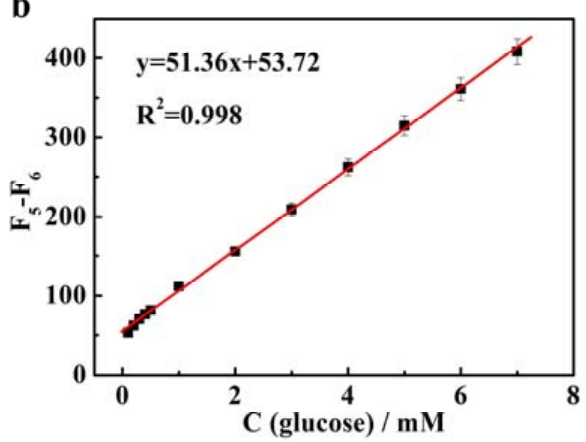

Figure 6. Fluorescence spectra of CNDs in the presence of different concentrations of glucose (a) and the corresponding linear range (b). The concentrations of $\mathrm{CNDs}, \mathrm{Cu}^{2+}$ and GOx were $0.014 \mathrm{mg} / \mathrm{mL}$, $600 \mathrm{nM}$, and $10 \mathrm{U} / \mathrm{mL}$, respectively.

Table 2. Comparison of analysis methods for the detection of glucose.

\begin{tabular}{ccccc}
\hline Method & Probe & Linear Range & LOD & Ref. \\
\hline Colorimetric detection & $\mathrm{MoS}_{2}$ nanosheets & $5-150 \mu \mathrm{M}$ & $1.2 \mu \mathrm{M}$ & 36 \\
Fluorescence & boronic acid modified carbon dots & $9-900 \mu \mathrm{M}$ & $1.5 \mu \mathrm{M}$ & 19 \\
Colorimetric detection & Gold nanoparticles & $0-5 \mathrm{mM}$ & - & 37 \\
Colorimetric detection & ZnS nanoparticles & $0.05-0.5 \mathrm{mM}$ & $36 \mu \mathrm{M}$ & 38 \\
Fluorescence & Copper nanoclusters & $10-100 \mu \mathrm{M}$ & $8 \mu \mathrm{M}$ & 39 \\
Colorimetric detection & Prussian blue nanoparticles & $0.1-50 \mu \mathrm{M}$ & $0.03 \mu \mathrm{M}$ & 40 \\
Fluorescence & carbon nitride dots & $1-100 \mu \mathrm{M}$ & $0.4 \mu \mathrm{M}$ & 41 \\
Fluorescence & CNDs & $0.1-7 \mathrm{mM}$ & $39.8 \mu \mathrm{M}$ & This work \\
\hline
\end{tabular}

\subsection{Selectivity for ATP and Glucose}

To examine the selectivity of this $\mathrm{CNDs}-\mathrm{Cu}^{2+}-\mathrm{H}_{2} \mathrm{O}_{2}$ system for ATP, other analogous molecules, including CTP, ADP, UTP, and GTP are investigated under the optimized conditions. As shown in Figure 7a, only the addition of ATP produces an obvious fluorescence recovery, suggesting the highly selectivity for ATP. Additionally, some interference substances, such as galactose, fructose, sucrose, mannose, lactose, sodium citrate, $\mathrm{AA}$, and $\mathrm{KCl}$, are evaluated. Due to the high specificity of GOx for glucose, other compounds cannot induce the effective fluorescence quenching of CNDs, indicating a high selectivity of our proposed sensing system for glucose.

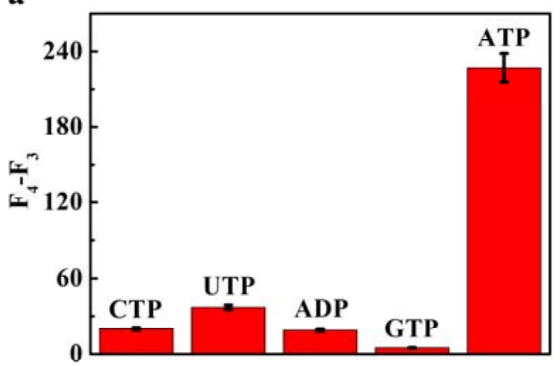

b

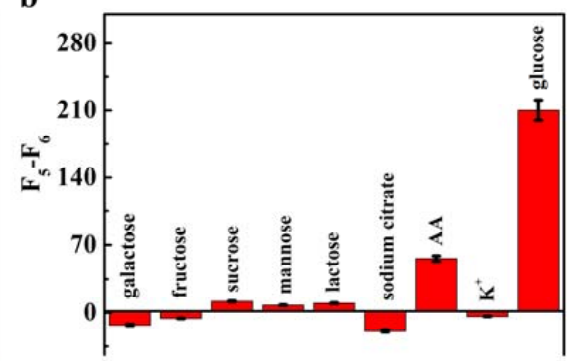

Figure 7. Selectivity of detection of ATP (a) and glucose (b). The concentrations of ATP and other interference substances in Figure $7 \mathrm{a}$ are $3 \mu \mathrm{M}$. In Figure $7 \mathrm{~b}$, glucose, and other substances are $3 \mathrm{mM}$.

\subsection{Detection of ATP and Glucose in Human Serum Samples}

To evaluate the applicability of this sensing system, the proposed strategy is used to determine ATP and glucose in human serum samples. The results are shown in Table 3, the concentration of ATP in human serum sample (without dilution) measured by our method is about $4.3 \mu \mathrm{M}$, which is consistent with the value detected by the high-performance liquid chromatograph (HPLC). With a 
standard addition method, the real samples are spiked with certain amounts of ATP and the satisfactory recoveries of ATP in the range from 102.4 to $106.4 \%$ are reached. On the other hand, the concentration of glucose in human serum sample (without dilution) detected by our method is about $3.41 \mathrm{mM}$, which is similar to the clinic value provided by local hospital $(3.78 \mathrm{mM})$. Next, the recoveries in the ranges from 98.0 to $104.8 \%$ are obtained by spiking different concentrations standard glucose solutions into human serum samples (Table 4). All results demonstrate that this proposed method is practicable, reliable, and can be used for simultaneous determination of ATP and glucose in human serum samples.

Table 3. Determination of ATP in serum samples.

\begin{tabular}{ccccc}
\hline Sample & Standard Added $\boldsymbol{\mu M}$ & Found Value $\boldsymbol{\mu M}$ & Recovery $(\%)$ & RSD $(\boldsymbol{n}=\mathbf{3}, \mathbf{\%})$ \\
\hline 1 & 0.0 & $0.433 *$ & - & 1.43 \\
2 & 0.1 & 0.537 & 104.0 & 1.68 \\
3 & 1.0 & 1.497 & 106.4 & 1.16 \\
4 & 5.0 & 5.553 & 102.4 & 1.61
\end{tabular}

* The concentration of ATP in human serum sample with diluted 10 times measured by our method is $0.43 \mu \mathrm{M}$, which is in agreement with the values detected by HPLC ( $4.1 \mu \mathrm{M}$ without dilution).

Table 4. Determination of glucose in serum samples.

\begin{tabular}{ccccc}
\hline Sample & Standard Added $\mathbf{~ m M}$ & Found Value $\mathbf{m M}$ & Recovery (\%) & RSD $(\boldsymbol{n}=\mathbf{3}, \mathbf{\%})$ \\
\hline 1 & 0 & $0.341^{*}$ & - & 1.38 \\
2 & 0.1 & 0.439 & 98.0 & 1.02 \\
3 & 1.0 & 1.389 & 104.8 & 1.52 \\
4 & 3.0 & 3.284 & 98.1 & 1.83 \\
\hline
\end{tabular}

* The concentration of glucose in human serum sample with diluted 10 times measured by our method is $0.341 \mathrm{mM}$, which is consistent with the clinical data provided by a local hospital ( $3.78 \mathrm{mM}$ without dilution).

\section{Conclusions}

Herein, a fluorescence sensing platform based on CNDs for the detection of ATP and glucose with superior sensitivity and selectivity has constructed. The sensing mechanism is that $\mathrm{Cu}^{2+}$ can react with $\mathrm{H}_{2} \mathrm{O}_{2}$ to generate $\cdot \mathrm{OH}$, which quenches the fluorescence of CNDs. Incorporating both ATP and glucose, which respond respectively to $\mathrm{Cu}^{2+}$ and $\mathrm{H}_{2} \mathrm{O}_{2}$, the measurements of ATP and glucose can be simultaneously achieved in human serum samples with satisfactory recoveries. Due to the abnormal levels of ATP and glucose closely related to some diseases, this assay has been proposed in an effort to find a proper candidate for use in routine clinical practice.

Supplementary Materials: The following are available online at http:/ /www.mdpi.com/1424-8220/18/7/2151/s1, Figure S1. Excitation-dependent fluorescence spectra of CNDs. Figure S2. Fluorescence spectra of CNDs upon addition of different concentrations of $\mathrm{Cu}^{2+}(\mathbf{a})$ in the presence of $\mathrm{H}_{2} \mathrm{O}_{2}(5 \mathrm{mM})$ and the corresponding linear ranges of $\mathrm{Cu}^{2+}(\mathbf{b})$. Figure S3. Fluorescence spectra of CNDs upon addition of different concentrations of $\mathrm{Cu}^{2+}$ in the absence of $\mathrm{H}_{2} \mathrm{O}_{2}$. Figure S4. Fluorescence spectra of CNDs upon addition of different concentrations of $\mathrm{H}_{2} \mathrm{O}_{2}(\mathbf{a})$ in the presence of $\mathrm{Cu}^{2+}(2 \mu \mathrm{M})$ and the corresponding linear ranges of $\mathrm{H}_{2} \mathrm{O}_{2}(\mathbf{b})$. Figure S5. Photographs of $\mathrm{Cu}^{2+}-\mathrm{H}_{2} \mathrm{O}_{2}-\mathrm{TMB}^{2}$ system with different concentrations of $\mathrm{Cu}^{2+}$ under visible light. Figure S6. Influence of $\mathrm{pH}$ values on $\mathrm{CNDs}-\mathrm{Cu}^{2+}-\mathrm{H}_{2} \mathrm{O}_{2}$ system. Figure S7. Influence of the incubation time between $\mathrm{Cu}^{2+}$ and ATP. The concentrations of $\mathrm{CNDs}_{2} \mathrm{H}_{2} \mathrm{O}_{2}, \mathrm{Cu}^{2+}$ and ATP were $0.014 \mathrm{mg} / \mathrm{mL}, 5 \mathrm{mM}, 600 \mathrm{nM}$ and $1 \mu \mathrm{M}$, respectively. Figure S8. Fluorescence spectra of CNDs in the presence of different concentrations of glucose (a) and the corresponding linear range from $0.1 \mathrm{mM}$ to $1 \mathrm{mM}(\mathbf{b})$. The concentrations of CNDs, $\mathrm{Cu}^{2+}$, and GOx were $0.014 \mathrm{mg} / \mathrm{mL}, 600 \mathrm{nM}$, and $10 \mathrm{U} / \mathrm{mL}$ respectively.

Author Contributions: F.Q. and J.L. conceived and designed the experiments; J.L. performed the experiments; F.Q. and J.L. wrote and checked the paper; and W.H., L.X. and J.Y. contributed the analysis of the experiment results.

Funding: This research was funded by the National Natural Science Foundation of China (Youth Fund Project) (21405093), the Scientific Research Foundation of Qufu Normal University (BSQD20130117), and the Experimental Research Project of Qufu Normal University (jp201716).

Conflicts of Interest: The authors declare no conflict of interest. 


\section{References}

1. Wei, Y.; Chen, Y.; Li, H.; Shuang, S.; Dong, C.; Wang, G. An exonuclease I-based label-free fluorometric aptasensor for adenosine triphosphate (ATP) detection with a wide concentration range. Biosens. Bioelectron. 2015, 63, 311-316. [CrossRef] [PubMed]

2. Ma, K.; Wang, H.; Li, H.; Wang, S.; Li, X.; Xu, B.; Tian, W. A label-free aptasensor for turn-on fluorescent detection of ATP based on AIE-active probe and water-soluble carbon nanotubes. Sens. Actuators B 2016, 230, 556-558. [CrossRef]

3. Hao, G.; Wang, D.; Sun, Y.; Yu, J.; Lin, F.; Cao, H. Association of blood glucose and lipid levels with complete blood count indices to establish a regression model. Biomed. Rep. 2017, 6, 339-345. [CrossRef] [PubMed]

4. Zhu, J.; Yu, C.; Chen, Y.; Shin, J.; Cao, Q.; Kim, J. A self-assembled amphiphilic imidazolium-based ATP probe. Chem. Commun. 2017, 53, 4342-4345. [CrossRef] [PubMed]

5. He, H.; Ma, V.P.Y.; Leung, K.H.; Chan, D.S.H.; Yang, H.; Cheng, Z.; Leung, C.H.; Ma, D.L. A label-free G-quadruplex-based switch-on fluorescence assay for the selective detection of ATP. Analyst 2012, 137, 1538-1540. [CrossRef] [PubMed]

6. Rastogi, L.; Karunasagar, D.; Sashidhar, R.B.; Giri, A. Peroxidase-like activity of gum kondagogu reduced/ stabilized palladium nanoparticles and its analytical application for colorimetric detection of glucose in biological samples. Sens. Actuators B 2017, 240, 1182-1188. [CrossRef]

7. Hu, A.; Liu, Y.; Deng, H.; Hong, G.; Liu, A.L.; Lin, X.; Xia, X.; Chen, W. Fluorescent hydrogen peroxide sensor based on cupric oxide nanoparticles and its application for glucose and 1-lactate detection. Biosens. Bioelectron. 2014, 61, 374-378. [CrossRef] [PubMed]

8. Lu, L.; Si, J.; Gao, Z.; Zhang, Y.; Lei, J.; Luo, H.; Li, N. Highly selective and sensitive electrochemical biosensor for ATP based on the dual strategy integrating the cofactor-dependent enzymatic ligation reaction with self-cleaving DNAzyme-amplified electrochemical detection. Biosens. Bioelectron. 2015, 63, 14-20. [CrossRef] [PubMed]

9. Schweinsberg, P.D.; Loo, T.L. Simultaneous analysis of ATP, ADP, AMP, and other purines in human erythrocytes by high-performance liquid chromatography. J. Chromatogr. B Biomed. Sci. Appl. 1980, 181, 103-107. [CrossRef]

10. Xu, M.; Gao, Z.; Zhou, Q.; Lin, Y.; Lu, M.; Tang, D. Terbium ion-coordinated carbon dots for fluorescent aptasensing of adenosine $5^{\prime}$-triphosphate with unmodified gold nanoparticles. Biosens. Bioelectron. 2016, 86, 978-984. [CrossRef] [PubMed]

11. Muthuraj, B.; Chowdhury, S.R.; Mukherjee, S.; Patra, C.R.; Iyer, P.K. Aggregation deaggregation influenced selective and sensitive detection of $\mathrm{Cu}^{2+}$ and ATP by histidine functionalized water-soluble fluorescent perylene diimide under physiological conditions and in living cells. RSC Adv. 2015, 5, 28211-28218. [CrossRef]

12. Moschou, E.A.; Sharma, B.V.; Deo, S.K.; Daunert, S. Fluorescence glucose detection: Advances toward the ideal in vivo biosensor. J. Fluoresc. 2004, 14, 535-547. [CrossRef] [PubMed]

13. Qu, F.; Guo, X.; Liu, D.; Chen, G.; You, J. Dual-emission carbon nanodots as a ratiometric nanosensor for the detection of glucose and glucose oxidase. Sens. Actuators B 2016, 233, 320-327. [CrossRef]

14. Liu, S.; Sun, Y. Co-immobilization of glucose oxidase and hexokinase on silicate hybrid sol-gel membrane for glucose and ATP detections. Biosens. Bioelectron. 2007, 22, 905-911. [CrossRef] [PubMed]

15. Shan, Z.; Lu, M.; Wang, L.; MacDonald, B.; MacInnis, J.; Mkandawire, M.; Zhang, X.; Oakes, K.D. Chloride accelerated Fenton chemistry for the ultrasensitive and selective colorimetric detection of copper. Chem. Commun. 2016, 52, 2087-2090. [CrossRef] [PubMed]

16. Cappella, P.; Giansanti, V.; Pulici, M.; Gasparri, F. From “Click” to “Fenton” chemistry for 5-bromo-2'-deoxyuridine determination. Cytom. Part A 2013, 83, 989-1000. [CrossRef] [PubMed]

17. Stohs, S.J.; Bagchi, D. Oxidative mechanisms in the toxicity of metal ions. Free Radic. Biol. Med. 1995, 18, 321-336. [CrossRef]

18. Wang, H.; Zhang, H.; Chen, Y.; Huang, K.; Liu, Y. A label-free and ultrasensitive fluorescent sensor for dopamine detection based on double-stranded DNA templated copper nanoparticles. Sens. Actuators B 2015, 220, 146-153. [CrossRef] 
19. Shen, P.; Xia, Y. Synthesis-modification integration: One-step fabrication of boronic acid functionalized carbon dots for fluorescent blood sugar sensing. Anal. Chem. 2014, 86, 5323-5329. [CrossRef] [PubMed]

20. De, B.; Karak, N. A green and facile approach for the synthesis of water soluble fluorescent carbon dots from banana juice. RSC Adv. 2013, 3, 8286-8290. [CrossRef]

21. Wang, F.; Xie, Z.; Zhang, H.; Liu, C.; Zhang, Y. Highly luminescent organosilane-functionalized carbon dots. Adv. Funct. Mater. 2011, 21, 1027-1031. [CrossRef]

22. Purbia, R.; Paria, S. A simple turn on fluorescent sensor for the selective detection of thiamine using coconut water derived luminescent carbon dots. Biosens. Bioelectron. 2016, 79, 467-475. [CrossRef] [PubMed]

23. Chen, J.; Li, Y.; Lv, K.; Zhong, W.; Wang, H.; Wu, Z.; Yi, P.; Jiang, J. Cyclam-functionalized carbon dots sensor for sensitive and selective detection of copper (II) ion and sulfide anion in aqueous media and its imaging in live cells. Sens. Actuators B 2016, 224, 298-306. [CrossRef]

24. Zu, F.; Yan, F.; Bai, Z.; Xu, J.; Wang, Y.; Huang, Y.; Zhou, X. The quenching of the fluorescence of carbon dots: A review on mechanisms and applications. Microchim. Acta 2017, 184, 1899-1914. [CrossRef]

25. Pham, A.N.; Xing, G.; Miller, C.J.; Waite, T.D. Fenton-like copper redox chemistry revisited: Hydrogen peroxide and superoxide mediation of copper-catalyzed oxidant production. J. Catal. 2013, 301, 54-64. [CrossRef]

26. Moffett, J.W.; Zika, R.G. Reaction kinetics of hydrogen peroxide with copper and iron in seawater. Environ. Sci. Technol. 1987, 21, 804-810. [CrossRef] [PubMed]

27. Millero, F.J.; Sharma, V.K.; Karn, B. The rate of reduction of copper (II) with hydrogen peroxide in seawater. Mar. Chem. 1991, 36, 71-83. [CrossRef]

28. Gray, R.D. Kinetics of oxidation of copper (I) by molecular oxygen in perchloric acid-acetonitrile solutions. J. Am. Chem. Soc. 1969, 91, 56-62. [CrossRef]

29. Wang, J.; Jiang, Y.; Zhou, C.; Fang, X. Aptamer-based ATP assay using a luminescent light switching complex. Anal. Chem. 2005, 77, 3542-3546. [CrossRef] [PubMed]

30. Zhu, Y.; Hu, X.; Shi, S.; Gao, R.; Huang, H.; Zhu, Y.; Lv, X.; Yao, T. Ultrasensitive and universal fluorescent aptasensor for the detection of biomolecules (ATP, adenosine and thrombin) based on DNA/Ag nanoclusters fluorescence light-up system. Biosens. Bioelectron. 2016, 79, 205-212. [CrossRef] [PubMed]

31. Wang, J.; Wang, L.; Liu, X.; Liang, Z.; Song, S.; Li, W.; Li, G.; Fan, C. A Gold Nanoparticle-Based Aptamer Target Binding Readout for ATP Assay. Adv. Mater. 2007, 19, 3943-3946. [CrossRef]

32. Tedsana, W.; Tuntulani, T.; Ngeontae, W. A highly selective turn-on ATP fluorescence sensor based on unmodified cysteamine capped CdS quantum dots. Anal. Chim. Acta 2013, 783, 65-73. [CrossRef] [PubMed]

33. Chen, Z.; Li, G.; Zhang, L.; Jiang, J.; Li, Z.; Peng, Z.; Deng, L. A new method for the detection of ATP using a quantum-dot-tagged aptamer. Anal. Bioanal. Chem. 2008, 392, 1185-1188. [CrossRef] [PubMed]

34. Zuo, X.; Song, S.; Zhang, J.; Pan, D.; Wang, L.; Fan, C. A target-responsive electrochemical aptamer switch (TREAS) for reagentless detection of nanomolar ATP. J. Am. Chem. Soc. 2007, 129, 1042-1043. [CrossRef] [PubMed]

35. Li, C.; Numata, M.; Takeuchi, M.; Shinkai, S. A sensitive colorimetric and fluorescent probe based on a polythiophene derivative for the detection of ATP. Angew. Chem. Int. Ed. 2005, 44, 6371-6374. [CrossRef] [PubMed]

36. Lin, T.; Zhong, L.; Guo, L.; Fu, F.; Chen, G. Seeing diabetes: Visual detection of glucose based on the intrinsic peroxidase-like activity of $\mathrm{MoS}_{2}$ nanosheets. Nanoscale 2014, 6, 11856-11862. [CrossRef] [PubMed]

37. Jiang, Y.; Zhao, H.; Lin, Y.; Zhu, N.; Ma, Y.; Mao, L. Colorimetric detection of glucose in rat brain using gold nanoparticles. Angew. Chem. 2010, 122, 4910-4914. [CrossRef]

38. Liu, Q.; Chen, P.; Xu, Z.; Chen, M.; Ding, Y.; Yue, K.; Xu, J. A facile strategy to prepare porphyrin functionalized $\mathrm{ZnS}$ nanoparticles and their peroxidase-like catalytic activity for colorimetric sensor of hydrogen peroxide and glucose. Sens. Actuators B 2017, 251, 339-348. [CrossRef]

39. Ling, Y.; Zhang, N.; Qu, F.; Wen, T.; Gao, Z.; Li, N.; Luo, H. Fluorescent detection of hydrogen peroxide and glucose with polyethyleneimine-templated Cu nanoclusters. Spectrochim. Acta Part A 2014, 118, 315-320. [CrossRef] [PubMed] 
40. Zhang, W.; Ma, D.; Du, J. Prussian blue nanoparticles as peroxidase mimetics for sensitive colorimetric detection of hydrogen peroxide and glucose. Talanta 2014, 120, 362-367. [CrossRef] [PubMed]

41. Liu, S.; Tian, J.; Wang, L.; Luo, Y.; Sun, X. A general strategy for the production of photoluminescent carbon nitride dots from organic amines and their application as novel peroxidase-like catalysts for colorimetric detection of $\mathrm{H}_{2} \mathrm{O}_{2}$ and glucose. RSC Adv. 2012, 2, 411-413. [CrossRef] 